Editorial

\title{
City as Flux: Interrogating the Changing Nature of Urban Change
}

\author{
Aseem Inam \\ Welsh School of Architecture, Cardiff University, UK; inama1@cardiff.ac.uk
}

Submitted: 16 December 2021 | Published: 11 January 2022

\begin{abstract}
What do we mean by the changing nature of urban change? First of all, in the 20th and 21st centuries, cities have been changing in different and dramatic ways, whether through grassroots mobilizations, through technological leaps, or through profit-driven speculations. Second, our understanding of how cities change has also been evolving, in particularly through empirical work that challenges the broad-brush universalizations of conventional thinking. The authors of the six selected articles take us through an around-the-world tour of cities and regions that range from Mulhouse in France to Dakar in Senegal to Las Vegas in the United States to Bogota in Colombia and beyond. Each author carefully examines the nature of urban change and how planners, developers, and citizens are either dealing with that change or even shaping it. Together, what the articles suggest is that we need a more fine-grained understanding of the city as flux in order to obtain better theoretical insights as well as urban practices that can better manage and ultimately shape urban change to benefit citizens, especially those who are marginalized.
\end{abstract}

\section{Keywords}

city as flux; urban change; urban practice; urban transformation

\section{Issue}

This editorial is part of the issue "City as Flux: Interrogating the Changing Nature of Urban Change" edited by Aseem Inam (Cardiff University).

(C) 2022 by the author(s); licensee Cogitatio (Lisbon, Portugal). This editorial is licensed under a Creative Commons Attribution 4.0 International License (CC BY).

\section{Introduction}

Urbanists-particularly those with backgrounds in professional fields like architecture, landscape architecture, urban design, and city planning - tend to be trained to view the city as an object that is planned, designed, and built according to definitive visions. In reality, the city is constantly changing at different timescales: by the hour, the week, the year, the decade, and the century. Thus, while urban geographers and historians have studied change for quite a while, such thinking has not yet permeated the world of urban practice in a meaningful manner. What would be the benefits if urbanism, both as an object of study and as a mode of practice, were to be approached from the perspective of flux rather than just an object? Why would such a reversal of ontological priorities be helpful? It would be helpful for three reasons.

First, it would enable researchers to obtain a more complete understanding of the micro-processes of urban change at work. For example, to understand urbanism more accurately, one must allow for emergence and surprise; that is, one must consider the possibility of urbanism having ramifications and implications beyond those initially imagined. Second, as well as not knowing much about the micro-processes of change, we often do not know enough about how change is actually accomplished. In order to understand this, we would need analysis of urbanism that was fine-grained enough to show how change was accomplished on the ground; that is, how ideas were translated into action, and by so doing, how they got modified, adapted, and changed. Third, a major cause of dissatisfaction with the traditional approach to change-the approach that gives priority to stability and treats change as an epiphenomenon-is paradigmatic. Strategies for change that are informed by that view often do not produce change, let alone transformation.

\section{Overview of the Thematic Issue}

The six selected articles in this thematic issue address these matters in a variety of ways. In the opening article, 
"Agents of Change in the Domestic Built Environment," Fani Kostourou (2022) adopts a more historical perspective by discussing the intent and context of the agents involved in the construction and transformation of the Cité Ouvrière in Mulhouse, in eastern France, from the mid-19th century until now. With 1,253 houses built for the workers of a textile factory between 1853 and 1897, Cité Ouvrière was the largest employer-constructed housing scheme of its time and established a precedent for many other European towns. Through what I would call an illuminating case study, Kostourou identifies the levels at which spatial agents operate, the means they use to instigate change, their dynamic relations, and the ways these are influenced by the wider historical context. One significant insight that she provides through this research is what she calls the "rotation of spatial agency" (Kostourou, 2022, p. 17). In this case, mutual monitoring and collaboration occurred between the private housing association of the Société Mulhousienne des Cités Ouvrières, who dominated the conception and making of the scheme, and the inhabitants, who drove its transformation over time. Such "rotation of spatial agency" allowed for the transformation of a low-rise uniform suburban settlement into a dense, socially diverse and heterogeneous city quarter.

Subsequent articles examine the phenomenon of "city as flux" in more contemporary periods. For example, in "How Does Water Behave? Unstable Milieu and Stable Agencements in Dakar's Flooded Suburbs," Romain Leclercq (2022) draws from the literature on assemblage to understand how people deal with untamed waters in flooded neighborhoods and at the city scale in Dakar based on ethnographic fieldwork conducted between 2015 and 2019. Leclerq frames the ways in which people deal with the different behaviors of the water in terms of specific "agencements" (i.e., composites of collective strategies and action that are oriented toward the solving of a problem). The first type is what he calls the "backfilling agencement," which is oriented toward the containment of water outside the house, and which tends to favor wealthier households that have enough money to elevate their houses. The second one is "co-produced flood response service," such as the motor-pumping of stagnant water, which is carried out through inter-individual negotiations with representatives of local governmental and non-governmental organizations. The third and related agencement is the "urban forum agencement," which gathers experts, dwellers, and decision-makers in order to collectively explore a problem and to reach a decision for a solution at the city scale. The fourth type is what he calls the "international slum service platform," which links international and national services to local demands in precarious neighborhoods through on-going negotiations and partnerships. By documenting, analyzing, and naming the different types of behaviors of water in the suburbs of Dakar as well as the responses in the form of agencements, the article contributes to an under- standing of cities as constantly changing and precarious milieus.

In urbanism, there has been a great deal of interest in "in-between" spaces for many years. In "The Changing Nature of In-Between Spaces in the Transformation Process of Cities," Magdalena Rembeza and Aleksandra Sas-Bojarska (2022) propose what they call a new approach for tapping into the potential of in-between spaces as public spaces based on landscape architecture, green/blue infrastructure, artistic strategies, and universal design in public spaces. In-between spaces are variously understood to be those spaces that are in-between purposefully designed structures and spaces and that are residual, under-utilized, and often deteriorating. The scale, scope, and benefits of possible actions based on this new approach are illustrated through three case studies: Turia Gardens in Valencia, Spain; Vistula River Boulevards in Warsaw, Poland; and Brooklyn Bridge Park in New York City, USA. Rembeza and Sas-Bojarska suggest that through this new approach, as demonstrated in the case studies, in-between spaces can become attractive and usable public spaces that contribute to the overall transformation of a city.

In some ways echoing the article on "Fits-and-Starts" later on in this issue, the article by Kevin Muldoon-Smith and Leo Moreton (2022) on "Planning Adaptation: Accommodating Complexity in the Built Environment" begins by discussing obsolescence and vacancy as parts of the traditional building life cycle, as tenants leave properties and move to new ones, a type of flux that they consider rightfully to be part of a building's DNA. What is new is structural disruptions, such as the Covid-19 global pandemic, tend to accelerate this type of flux. The question is: How does planning, in this case in England in the UK, deal with such flux? Findings based on interviews with a sample of local authority planners, combined with an institutional analysis of planning practice since the 1947 Town and Country Planning Act, suggest that the discipline of planning in England is struggling with the reality of flux. Muldoon-Smith and Moreton situate their findings in a new reading of the complex adaptive systems literature, arguing that planning practice needs to embrace uncertainty, rather than eradicate it, in order to enable adaptation to ongoing and sometimes large-scale flux in the material city. The argument is that those involved in building adaptation (e.g., planners, developers, landlords, tenants) should revisit the spirit of the 1947 Town and Country Planning Act to create a planning system that is nimble yet rigorous enough to facilitate timely adaptation to accommodate and support dynamic change in the material city.

The article "Fits-and-Starts: The Changing Nature of the Material City" by Aseem Inam (2022) pushes our understanding of cities in flux much further by examining one type of prominent urban change"fits-and-starts" - which is concentrated in space and time and that nonetheless has high economic and environmental costs. The case study in Las Vegas is 
particularly fascinating because as a city of apparent extremes, it not only reveals in clear relief phenomena that are present in the capitalist city, but it also offers insights into basic patterns of decision-making that actually shape-or design-it. Part one of the case study examines the overall fits-and-starts type of urban change between 1993 and 2016 on the famed Las Vegas Strip, and part two examines more in-depth the decision-making behind radical changes on one of the sites on the Strip, which is the Desert Inn, subsequently replaced by the Wynn Las Vegas casino-hotel-resort complex. In a highly accelerated version of the fits-and-starts urban change that many contemporary cities experience, Las Vegas demolished much of its recent history with the implosions of 13 casinos, hotels, and resorts on the Strip-the Dunes, Landmark, Hacienda, Sands, Aladdin, El Rancho, Desert Inn, Boardwalk, Bourbon Street, New Frontier, Stardust, Clarion, and Riviera-and these were soon replaced by some of the new icons, such as the Bellagio, Venetian, Mandalay Bay, Planet Hollywood, Wynn, and City Center. Based on a review of the literature and original field research, Inam provides two major insights into how human perception and decision-making drives this type of fits-and-starts urban change in cities of capitalism in the USA and elsewhere, which are manufactured obsolescence and future speculation. Manufactured obsolescence occurs when a building is only a few decades old and is structurally and functionally sound but is made to appear outdated and unsatisfactory for present and future needs by real estate agents, private investors, property owners, and real estate developers. Future speculation is not only a corollary of manufactured obsolescence but also what often pushes for such type of obsolescence in the first place and is about formulating expectations about the future-and higher-return on investment.

The final article in this thematic issue, "Change by Activism: Insurgency, Autonomy and Political Activism in Potosí-Jerusalén, Bogotá, Colombia," by Juan Usubillaga (2022), directly addresses how innovative urban practices deal with the changing nature of urban change. The type of practices the article focuses on are social movements and political activists that are rising up and inhabiting urban spaces as sites of contestation as they constantly face spatial manifestations of power. Usubillaga contributes to ongoing discussions on the role of activism in the field of urbanism by engaging with two concepts that have emerged particularly from the global south-insurgency and autonomy. Through a historical account of the building of the Potosí-Jerusalén neighborhood in Bogotá in the 1980s, it illustrates how both concepts can provide new insight into urban change by activism. On the one hand, the concept of insurgency helps unpack a mode of bottom-up action that inaugurates political spaces of contestation with the state, while autonomy helps reveal the complex nature of political action and the visions of urban transformation it entails. Such experiences from cities of the global south are essential for challenging the traditional primacy of urban theory that is produced in the global north. The building of Potosí in Bogotá is not an isolated or exceptional phenomenon but rather part of larger struggles that tend to be marginalized in the way change is conceptualized and thus has to be brought into conversation with different experiences in other cities, which this thematic issue endeavors to do.

\section{Conclusion}

This thematic issue of Urban Planning on the topic "City as Flux: Interrogating the Changing Nature of Urban Change" invited scholars who not only study urban change but are also interested in matters of practice, including those that can lead to meaningful change such as fundamental urban transformation. Authors were encouraged to present research that not only challenges our conventional understanding of the city as a static object, but also enables our understanding of how urban change actually occurs. The thematic issue thus offers a series of valuable empirical insights as well as theoretical implications for different modes of practice that engage directly with urban change. Collectively, then, what the articles in this issue suggest is that to truly understand the city as flux and the changing nature of urban change, future research should try to have three primary objectives. One is to be theoretically rigorous, especially by drawing recent research from a variety of disciplines and sources that defies conventional thinking. The second is to be empirical and contextually-grounded such that we understand how phenomena of urban change operate in different cities over time. Third, is to draw lessons that could be generalizable (rather than universal), in the sense of a representative situation that can bring together instances sharing some properties (e.g., urban change in contemporary cities of capitalism, in cities of the global south, in cities with highly regulated planning systems). We invite you to join the critical public conversation in this issue.

\section{Conflict of Interests}

The author declares no conflict of interests.

\section{References}

Inam, A. (2022). Fits-and-starts: The changing nature of the material city. Urban Planning, 7(1), 56-71.

Kostourou, F. (2022). Agents of change in the domestic built environment. Urban Planning, 7(1), 5-20.

Leclercq, R. (2022). How does water behave? Unstable milieu and stable agencements in Dakar's flooded suburbs. Urban Planning, 7(1), 21-31.

Muldoon-Smith, K., \& Moreton, L. (2022). Planning adaptation: Accommodating complexity in the built environment. Urban Planning, 7(1), 44-55.

Rembeza, M., \& Sas-Bojarska, A. (2022). The changing 
nature of in-between spaces in the transformation process of cities. Urban Planning, 7(1), 32-43.

Usubillaga, J. (2022). Change by activism: Insurgency, autonomy and political activism in Potosí-Jerusalén, Bogotá, Colombia. Urban Planning, 7(1), 72-81.

\section{About the Author}

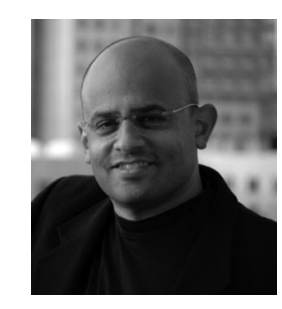

Aseem Inam (PhD) is the inaugural chair in urban design and professor at Cardiff University, and founding director of the research-based practice TRULAB: Laboratory for Designing Urban Transformation. $\mathrm{He}$ is the author of the books Planning for the Unplanned and Designing Urban Transformation. He has carried out numerous funded research projects and published peer-reviewed scholarly articles in international journals on urbanism, urban practice, and urban transformation. He has practiced as an award-winning urbanist in Brazil, Canada, France, Greece, India, Morocco, the United Kingdom, and the United States. 